\title{
Occurrence of $\mathbf{5}^{\prime}$-Deoxyadenosylcobalamin and Its Physiological Function as the Coenzyme of Methylmalonyl-CoA Mutase in a Marine Eukaryotic Microorganism, Schizochytrium limacinum SR21
}

\author{
Emi MiYAmoto ${ }^{1}$, Yuri TANIOKA ${ }^{2}$, Tsugiyo YUKINO ${ }^{3}$, Masahiro HAYASHI ${ }^{4}$, \\ Fumio WATANABE ${ }^{5}$ and Yoshihisa NAKANO ${ }^{2}$ \\ ${ }^{1}$ Department of Health and Nutrition, Nagasaki International University, Sasebo 859-3298, Japan \\ ${ }^{2}$ Department of Applied Biological Chemistry, Osaka Prefecture University, Sakai 599-5831, Japan \\ ${ }^{3}$ Department of Nutritional Sciences, Nayoro City University, Nayoro 096-8641, Japan \\ ${ }^{4}$ Department of Biological Production and Environmental Science, Faculty of \\ Agriculture, University of Miyazaki, Miyazaki 889-2192, Japan \\ ${ }^{5}$ School of Agricultural, Biological and Environmental Sciences, Faculty \\ of Agriculture, Tottori University, Tottori 680-8553, Japan
}

(Received June 29, 2007)

\begin{abstract}
Summary A marine eukaryotic microorganism, Schizochytrium limacinum SR21, had the ability to absorb and accumulate exogenous cobalamin, which was converted to the cobalamin coenzymes $5^{\prime}$-deoxyadenosylcobalamin $(20.1 \%)$ and methylcobalamin $(29.6 \%)$. A considerably high activity (about $38 \mathrm{mU} / \mathrm{mg}$ protein) of 5'-deoxyadenosylcobalamin-dependent methylmalonyl-CoA mutase (EC 5.4.99.2) involved in amino acid and odd-chain fatty acid metabolism was found in the cell homogenate of S. limacinum SR21. The enzyme was purified to homogeneity and characterized.
\end{abstract}

Key Words cobalamin, 5'-deoxyadenosylcobalamin, vitamin $\mathrm{B}_{12}$, methylmalonyl-CoA mutase, Schizochytrium limacinum SR21

Schizochytrium limacinum SR21, a thraustochytrid (Labyrinturomycota) is an unusual marine eukaryotic microorganism that is closely related to heterokont algae (1) because it contains substantial amounts of docosahexaenoic acid (DHA). It is suitable for use as an excellent source of DHA $(2,3)$. Indeed, Franklin et al. (4) have demonstrated that feeding Schizochytrium cells to dairy cows increases the concentration of DHA in their milk.

Recently, addition of vitamin $\mathrm{B}_{12}$ or cyanocobalamin $(\mathrm{CN}-\mathrm{Cbl})$ to the cultivation medium of $S$. limacinum SR21 has been reported to decrease the ratio of oddnumbered to even-numbered fatty acids in cultured cells $(5,6)$. The result suggested that the cells had the ability to take up $\mathrm{CN}-\mathrm{Cbl}$ and then synthesize $5^{\prime}$-deoxyadenosylcobalamin (AdoCbl), which is the coenzyme of methylmalonyl-CoA mutase (MCM) (EC 5.4.99.2). The enzyme catalyzes isomerization of $(R)$-methylmalonylCoA to succinyl-CoA, an intermediate in the Krebs cycle, and thus is involved in the metabolism of oddnumbered fatty acids and branched-chain amino acids.

Although, our preliminary experiments indicated that $S$. limacinum SR21 requires $\mathrm{Cbl}$ for growth, there is no detailed information about whether the $\mathrm{CN}-\mathrm{Cbl}$ taken up by the cells is indeed converted into the $\mathrm{Cbl}$ coenzymes and what kind of Cbl-dependent enzymes occur in the cells. To clarify the physiological roles of $\mathrm{Cbl}$ in this organism, we demonstrate occurrence of the

E-mail: miyamo@niu.ac.jp
$\mathrm{Cbl}$ coenzymes and their related enzymes in $\mathrm{CN}-\mathrm{Cbl}-$ supplemented cells. The AdoCbl-dependent MCM involved in the metabolism of odd-numbered fatty acids was characterized.

\section{MATERIALS AND METHODS}

Organism and culture. Schizochytrium limacinum SR21 (IFO032693) was grown in $500 \mathrm{~mL}$ shaking flasks at $28^{\circ} \mathrm{C}$ for $4 \mathrm{~d}$. The basal medium consisted of $3 \%(\mathrm{w} / \mathrm{v})$ glucose and $1 \%(\mathrm{w} / \mathrm{v})$ yeast extract in half strength artificial seawater (Marine Art High, Senjyu Seiyaku Co., Ltd., Osaka, Japan) (pH 6.0). CN-Cbl $(50 \mu \mathrm{g} / \mathrm{mL}$ medium) was added to the basal medium. After cultivation for $4 \mathrm{~d}$, cells were harvested by centrifugation $(1,500 \times g, 10 \mathrm{~min})$ and washed thrice with distilled water and stored at $-80^{\circ} \mathrm{C}$.

Enzyme assay. $\mathrm{MCM}$ was assayed at $37^{\circ} \mathrm{C}$ by a modified high-performance liquid chromatography (HPLC) method described previously (7), using Shimadzu apparatus (Kyoto, Japan). The MCM activity was calculated from the amount of succinyl-CoA formed. One unit of enzyme activity was defined as the amount of enzyme that catalyzed the formation of succinyl-CoA at the rate of $1 \mu \mathrm{mol} / \mathrm{min}$.

Cbl assay. Cbl was extracted and assayed microbiologically with Lactobacillus delbrueckii subsp. lactis (formerly Lactobacillus leichmannii) ATCC7830 as described previously (8). A Cbl assay medium for L. delbrueckii ATCC7830 was obtained from Nissui (Tokyo, Japan). The turbidity $(\% \mathrm{~T})$ of the test culture of $L$. delbrueckii 
ATCC7830 grown at $37^{\circ} \mathrm{C}$ for $16-21 \mathrm{~h}$ was measured at $660 \mathrm{~nm}$ with a UV-1600 UV-Visible spectrophotometer.

Analysis of Cbl coenzymes from S. limacinum SR21. Analysis of $\mathrm{Cbl}$ coenzymes was done according to the method of reference (9). An aliquot (20 $\mu \mathrm{L})$ of the sample was loaded into a reversed-phase HPLC column (Wakosil-II 5C18 RS, $\varphi 4.6 \times 150 \mathrm{~mm}$; particle size, 5 $\mu \mathrm{m})$ that had been equilibrated with $5 \%(\mathrm{v} / \mathrm{v})$ methanol solution containing $0.1 \%(\mathrm{v} / \mathrm{v})$ acetic acid at $40^{\circ} \mathrm{C}$. The flow rate was $1 \mathrm{~mL} / \mathrm{min}$. Cbl compounds were eluted with a linear gradient of methanol [from $0 \%$ to $90 \%$ of $50 \%(\mathrm{v} / \mathrm{v})$ methanol solution containing $0.1 \%(\mathrm{v} / \mathrm{v})$ acetic acid] for $30 \mathrm{~min}$. Fractions $(1 \mathrm{~mL})$ were collected from the HPLC column, evaporated to dryness under reduced pressure, and dissolved in $1 \mathrm{~mL}$ of $10 \mathrm{~mm}$ acetate buffer, $\mathrm{pH} 4.5$, containing $0.2 \mathrm{~g} / \mathrm{L} \mathrm{KCN}$. These fractions were boiled for $30 \mathrm{~min}$ at $98^{\circ} \mathrm{C}$ and centrifuged at $3,000 \times g$ for $10 \mathrm{~min}$. Each supernatant fraction was used for $\mathrm{Cbl}$ assay. The retention times of authentic hydroxocobalamin $(\mathrm{OH}-\mathrm{Cbl})$, sulfitocobalamin $\left(\mathrm{SO}_{3}-\right.$ $\mathrm{Cbl}), \mathrm{CN}-\mathrm{Cbl}$, AdoCbl, and methylcobalamin $(\mathrm{MeCbl})$ were $12.4,16.0,20.0,23.5$, and $27.8 \mathrm{~min}$, respectively.

Purification of MCM from S. limacinum SR21. The stored Schizochytrium cells (about $55 \mathrm{~g}$ wet weight) were suspended in $110 \mathrm{~mL}$ of $10 \mathrm{~mm}$ potassium phosphate buffer, $\mathrm{pH} 7.0$, containing $10 \%(\mathrm{w} / \mathrm{v})$ sucrose. The cells were disrupted by sonic oscillation $(10 \mathrm{kHz}, 10 \mathrm{~s} \times 6)$ and centrifuged at $10,000 \times g$ for $10 \mathrm{~min}$. AdoCbl was added to the supernatant fraction at a final concentration of $10 \mu \mathrm{M}$ and left overnight in the dark at $4^{\circ} \mathrm{C}$ to form the holo-enzyme. The treated solution was precipitated with $\left(\mathrm{NH}_{4}\right)_{2} \mathrm{SO}_{4}$, and the 40-60\% (w/w) $\left(\mathrm{NH}_{4}\right)_{2} \mathrm{SO}_{4}$ saturation was collected and dissolved in $10 \mathrm{~mL}$ of $10 \mathrm{~mm}$ potassium phosphate buffer, $\mathrm{pH}$ 7.0, containing $10 \%(\mathrm{w} / \mathrm{v})$ sucrose. The solution was dialyzed overnight against $1.5 \mathrm{~L}$ of $10 \mathrm{~mm}$ potassium phosphate buffer, $\mathrm{pH}$ 7.0, containing $10 \% \quad(\mathrm{w} / \mathrm{v})$ sucrose. The dialyzed solution was put on a column $(2.4 \mathrm{~cm} \times 20 \mathrm{~cm})$ of TSKgel QAE-Toyopearl HW55C equilibrated with $10 \mathrm{~mm}$ potassium phosphate buffer, $\mathrm{pH} 7.0$, containing $10 \%(\mathrm{w} / \mathrm{v})$ sucrose, and eluted with $300 \mathrm{~mL}$ of a linear gradient $(0-0.5 \mathrm{M})$ of $\mathrm{KCl}$ in the same buffer. The active fractions were collected and concentrated in Centriprep-30 centrifugal concentrator (Millipore Co., Bedford, MA, USA) up to a final volume of $1.0 \mathrm{~mL}$. The concentrated solution $(1.0 \mathrm{~mL})$ was put on a HiLoad 16/60 Superdex $200 \mathrm{pg}$ column (GE Healthcare Bio-Sciences Corp., Piscataway, NJ, USA) equilibrated with $10 \mathrm{~mm}$ potassium phosphate buffer, $\mathrm{pH} 7.0$, containing $10 \%(\mathrm{w} / \mathrm{v})$ sucrose and $200 \mathrm{~mm}$ $\mathrm{KCl}$, and eluted with the same buffer. The active fractions were combined and dialyzed overnight against $1 \mathrm{~L}$ of $10 \mathrm{~mm}$ potassium phosphate buffer, $\mathrm{pH} 7.0$, containing $10 \%(\mathrm{w} / \mathrm{v})$ sucrose. The dialyzed solution was concentrated in a Centricon-30 microconcentrator (Millipore) up to a final volume of $1.0 \mathrm{~mL}$. The concentrated solution $(1.0 \mathrm{~mL})$ was put on a Mono Q column HR 5/5 (GE Healthcare Bio-Sciences Corp.) equilibrated with 10
$\mathrm{mM}$ potassium phosphate buffer, $\mathrm{pH}$ 7.0, containing $10 \%(\mathrm{w} / \mathrm{v})$ sucrose, and eluted with $40 \mathrm{~mL}$ of a linear gradient $(0-0.5 \mathrm{M})$ of $\mathrm{KCl}$ in the same buffer. The active fractions were combined and desalted in a Centricon-30 microconcentrator (Millipore). The solution was put on a Mono Q column HR 5/5 and eluted with $40 \mathrm{~mL}$ of a linear gradient $(0.1-0.4 \mathrm{M})$ of $\mathrm{KCl}$ in the same buffer. The peak fraction of the enzyme activity was concentrated to a final volume of $0.5 \mathrm{~mL}$ in the Centricon-30 and stored at $-80^{\circ} \mathrm{C}$.

Polyacrylamide gel electrophoresis (PAGE) in the presence or absence of SDS. A precasted slab gel (READY GELS J, Bio-Rad) was used for electrophoresis with 5$20 \%$ linear gradient polyacrylamide in the presence or absence of SDS. A purified enzyme (1 $\mu \mathrm{g}$ of protein) was run on the precasted gel in the presence or absence of SDS at constant current $(12 \mathrm{~mA}$ per gel) with bromophenol blue as a migration marker. After electrophoresis, proteins in the gel were stained with Simply Blue SafeStain (Invitrogen, Carlsbad, CA, USA) and destained in distilled water according to the manufacturer's instruction. Standard proteins (recombinant protein; 10; 15; 20; 25; 37; 50; 75; 100; 150; 250 $\mathrm{kDa})$ in a Bio-Rad kit were used for the calibration of molecular mass of the subunit of the S. limacinum SR21 MCM.

Gel filtration experiments. The molecular mass of the Schizochytrium MCM was determined with a HiLoad 16/ 60 Superdex $200 \mathrm{pg}$ gel filtration column (GE Healthcare Bio-Sciences Corp.) using the BioLogic HR chromatography system (Bio-Rad). The column was equilibrated with $10 \mathrm{~mm}$ potassium phosphate buffer, $\mathrm{pH}$ 7.0, containing $10 \%(\mathrm{w} / \mathrm{v})$ sucrose and $200 \mathrm{~mm} \mathrm{KCl}$, and eluted with the same buffer. The molecular mass of the MCM was calibrated with blue dextran (average $2,000.0 \mathrm{kDa})$, apoferritin from horse spleen $(480.0$ $\mathrm{kDa})$, alcohol dehydrogenase from yeast $(150.0 \mathrm{kDa})$, albumin from bovine serum $(66.0 \mathrm{kDa})$, and cytochrome $c$ from horse heart $(12.4 \mathrm{kDa})$. The proteins were monitored by measuring the absorbance at 280 $\mathrm{nm}$.

Optimum temperature and $p H$. The optimum temperature of the enzyme was determined by incubating at temperatures $\left(10,15,20,25,30,35\right.$, and $\left.40^{\circ} \mathrm{C}\right)$ for 5 min at $\mathrm{pH}$ 7.0.

The optimum $\mathrm{pH}$ of the enzyme was determined by incubation at various $\mathrm{pH}$ values $(5.1,5.8,7.1,7.5,8.0$, and 8.8) in $10 \mathrm{~mm}$ Tris-acetate buffer for $5 \mathrm{~min}$ at $37^{\circ} \mathrm{C}$.

Effect of SH-inhibitors. The enzyme activity was assayed at $37^{\circ} \mathrm{C}$ for $5 \mathrm{~min}$ at $\mathrm{pH} 7.0$ using the purified enzyme treated with $3 \mathrm{~mm}$ of SH-inhibitors [ $\mathrm{N}$-ethylmaleimide, 5,5'-dithiobis-(2-nitrobenzoic acid), and iodoacetamide] at $37^{\circ} \mathrm{C}$ for $10 \mathrm{~min}$ at $\mathrm{pH}$ 7.0.

Effect of monovalent and divalent cations. The purified MCM was dialyzed overnight against $1 \mathrm{~L}$ of $10 \mathrm{~mm}$ Tris$\mathrm{HCl}$ buffer, $\mathrm{pH} 7.0$, containing $10 \%(\mathrm{w} / \mathrm{v})$ sucrose. Using the dialyzed enzyme, the enzyme activity was assayed at $37^{\circ} \mathrm{C}$ for $5 \mathrm{~min}$ at $10 \mathrm{~mm}$ Tris- $\mathrm{HCl}$ buffer $(\mathrm{pH}$ 7.0) in the presence of each monovalent and divalent cation $\left(\mathrm{NaCl}, \mathrm{KCl}, \mathrm{NH}_{4} \mathrm{Cl}, \mathrm{RbCl}, \mathrm{CsCl}, \mathrm{LiCl}, \mathrm{CoCl}_{2}, \mathrm{MnCl}_{2}\right.$, 
$\mathrm{FeCl}_{2}$, and $\mathrm{MgCl}_{2}$, all at $3 \mathrm{~mm}$ ).

Effect of substrate concentrations. In the case of determination of $\mathrm{Km}$ values for methylmalonyl-CoA and succinyl-CoA (reverse reaction), the enzyme activity was assayed at various concentrations of $(R, S)$-methylmalonyl-CoA $(0,0.005,0.0063,0.0084,0.0125,0.025$, $0.050,0.10,0.20,0.4,0.8,1.6,3.2 \mathrm{~mm})$ or succinylCoA $(0,0.5,0.625,0.835,1.25,2.5,5.0 \mathrm{mM})$ under standard assay conditions.

Protein assay. Protein was assayed using a Bio-Rad protein assay kit, with ovalbumin as standard according to the manufacturer's instructions.

\section{RESULTS AND DISCUSSION}

Occurrence of Cbl coenzymes in S. limacinum SR21

S. limacinum SR 21 contained $1.4 \mathrm{mg}$ of $\mathrm{Cbl}$ per $100 \mathrm{~g}$ dry cell weight. To elucidate whether Cbl coenzymes, AdoCbl, and MeCbl occur in the cells, Cbl-compounds were extracted, separated by a reversed-phase HPLC, and determined by the microbiological assay method. The Schizochytrium cells contained five known types of biologically active Cbl-compounds with different upper-

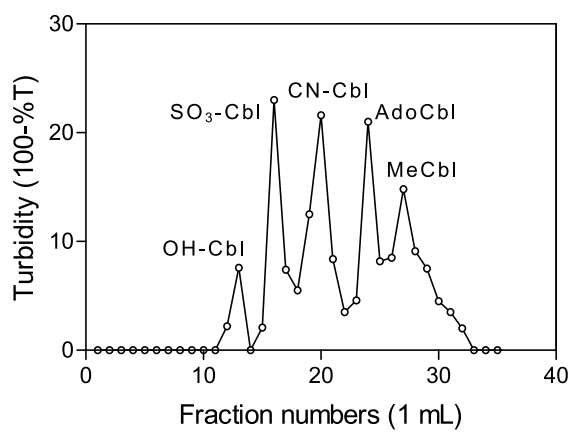

Fig. 1. Occurrence of $\mathrm{Cbl}$ coenzymes in the $S$. limacinum SR21. Cbl-compounds were extracted from the Schizochytrium cells by boiling with $80 \%(\mathrm{v} / \mathrm{v})$ ethanol solution. The extract was concentrated and treated with HPLC. Cbl was assayed in the eluate from HPLC by the microbiological method. Detailed procedures are described in the text. The data are the typical pattern of Cbl-compounds found in Schizochytrium cells from three independent experiments.

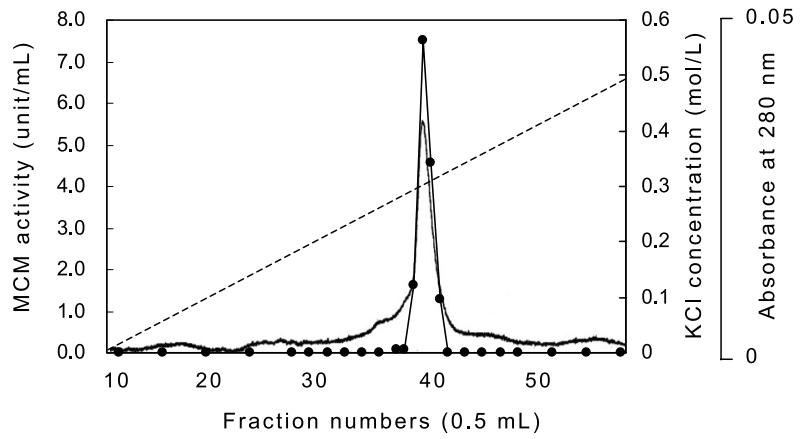

Fig. 2. Elution profile of the $S$. limacinum SR 21 MCM activity during final Mono-Q column chromatography. (-), absorbance at $280 \mathrm{~nm}$; $(\bullet)$, MCM activity; and (---), $\mathrm{KCl}$ concentration. A typical elution pattern from three independent experiments is shown. ligands [approximately $\mathrm{OH}-\mathrm{Cbl}, 5.8 \%$; $\mathrm{SO}_{3}-\mathrm{Cbl}, 18.2 \%$; CN-Cbl, 27.3\%; AdoCbl, 20.1\%; and MeCbl, 29.6\%] (Fig. 1). The results indicate that S. limacinum SR21 has the ability to take up and accumulate exogenous $\mathrm{CN}$ $\mathrm{Cbl}$; half of the $\mathrm{CN}-\mathrm{Cbl}$ taken up by the cells was converted to the $\mathrm{Cbl}$ coenzymes. Considerable amounts $(18.2 \%)$ of $\mathrm{SO}_{3}-\mathrm{Cbl}$ were also found in the cell homogenate. $\mathrm{SO}_{3}-\mathrm{Cbl}$ has been reported to be formed by the decomposition of glutathionylcobalamin, an intermediate in the conversion from $\mathrm{CN}-\mathrm{Cbl}$ to AdoCbl (10). These results suggest that the enzymatic system for synthesis of the $\mathrm{Cbl}$ coenzymes is present in S. limacinum SR21.

MCM activity in a cell homogenate of S. limacinum SR21

Our preliminary experiments indicated that $S$. limacinum SR21 had the highest MCM (holo-form) activity (about $19.4 \mathrm{mU} / \mathrm{mg}$ protein) in a cell homogenate among the twelve species of thraustochytrids (about $0.7-14.8 \mathrm{mU} / \mathrm{mg}$ protein) tested.

Schizochytrium MCM activity increased significantly up to about $38 \mathrm{mU} / \mathrm{mg}$ protein in the presence of AdoCbl. The results indicate that about $50 \%$ of MCM found in the Schizochytrium cells occurred as the apoenzyme.

Purification of MCM from S. limacinum SR21

A cell homogenate of S. limacinum SR21 was incubated with $10 \mu \mathrm{M} \mathrm{AdoCbl}$ at $4^{\circ} \mathrm{C}$ overnight in the dark so that the apo-enzyme could be converted to the holoenzyme. This treatment significantly increased the MCM activity ( $76 \mathrm{mU} / \mathrm{mg}$ protein). The holo-MCM was purified to homogeneity. Figure 2 shows the elution profile of the Schizochytrium MCM during Mono-Q HR $5 / 5$ column chromatography (the final purification step). The enzyme activity gave a single peak at $0.3 \mathrm{~m}$ $\mathrm{KCl}$. The purification procedures for MCM from a homo-

A

B

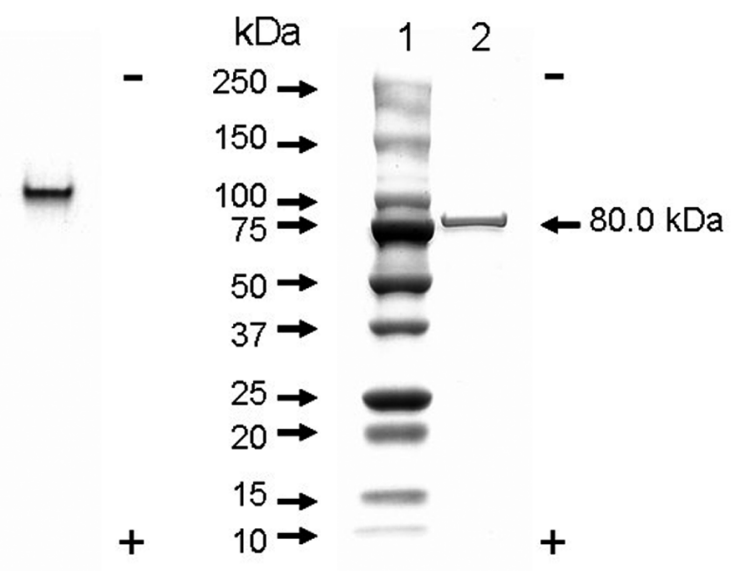

Fig. 3. PAGE of MCM from the final puritication step. A, purified enzyme ( $1 \mu \mathrm{g}$ protein) in the absence of SDS. B 1, molecular mass standard proteins; 2 , the purified enzyme ( $1 \mu \mathrm{g}$ protein) in the presence of SDS. Typical migration patterns of the purified enzyme and preparations obtained in the purification steps are shown. 
Table 1. Purification of methylmalonyl-CoA mutase from Schizochytrium limacinum SR21.

\begin{tabular}{lcccc}
\multicolumn{1}{c}{ Step } & $\begin{array}{c}\text { Total protein } \\
(\mathrm{mg})\end{array}$ & $\begin{array}{c}\text { Total activity } \\
\text { (units) }\end{array}$ & $\begin{array}{c}\text { Specific activity } \\
\text { (units/mg protein) }\end{array}$ & $\begin{array}{c}\text { Yield } \\
(\%)\end{array}$ \\
\hline $\begin{array}{l}\text { Crude homogenate } \\
\begin{array}{l}\text { 40-60\% }\left(\mathrm{NH}_{4}\right)_{2} \mathrm{SO}_{4} \\
\quad \text { fractionation }\end{array}\end{array}$ & $4,533.4$ & 344.6 & 0.076 & 100.0 \\
$\begin{array}{l}\text { TSKgel } \\
\text { QAE-Toyopearl 550 }\end{array}$ & $1,500.9$ & 350.1 & 0.23 & 101.6 \\
$\begin{array}{l}\text { HiLoad 16/60 } \\
\text { Superdex 200 pg }\end{array}$ & 393.2 & 260.2 & 0.66 & 75.5 \\
1st Mono-Q & 43.21 & 89.81 & 2.08 & 26.1 \\
2nd Mono-Q & 0.91 & 9.66 & 10.62 & 2.8 \\
\hline
\end{tabular}

genate of S. limacinum SR21 are summarized in Table 1. The MCM was purified about 163-fold in a yield of $1.6 \%$ from the homogenate. Polacrylamide gel electrophoresis (PAGE) of the purified enzyme in the absence of SDS using a precast gel showed a single protein band (Fig. 3A).

\section{Molecular mass}

The apparent molecular mass of the enzyme was calculated to be $160 \pm 5 \mathrm{kDa}$ by Superdex $200 \mathrm{pg}$ gel filtration. SDS-PAGE of the purified enzyme gave a single protein band with an apparent molecular mass of $80 \pm 5 \mathrm{kDa}$ (Fig. 3B), indicating that the Schizochytrium enzyme is composed of two identical subunits.

The Schizochytrium MCM has a similar subunit structure to the enzymes of human livers (11), an intestinal worm (12), a marine alga (Pleurochrysis carterae) (7), and a root-nodule bacterium (Sinorhizobium meliloti) (13). The enzymes of an anaerobic bacterium (Propionibacterium shermanii) (14) and an aerobic bacterium (Methylobacterium extorquencs NR-1) (15) consist of two non-identical subunits with molecular masses of 79-85 $\mathrm{kDa}$ and 67-70 kDa.

Some properties of the Schizochytrium MCM

The optimum temperature of the enzyme was $37^{\circ} \mathrm{C}$. The optimum $\mathrm{pH}$ of the enzyme was 7.0.

The apparent $\mathrm{Km}$ values of the enzyme were 0.68 $\mathrm{mm}$ for $(R, S)$ methylmalonyl-CoA and $2.4 \mathrm{~mm}$ for succinyl-CoA (the reverse reaction).

The purified Schizochytrium MCM activity was not affected by the usual SH-reagents [iodoacetamide, $\mathrm{N}$ ethylmaleimide, and 5,5'-dithiobis-(2-nitrobenzoic acid)] at $3 \mathrm{~mm}$.

The MCM activities of $P$. shermanii (16), M. extorquencs NR-1 (15), and an intestinal worm (12) are not affected by the SH-inhibitors, but those of $S$. meliloti (13), P. carterae (7), and human livers (11) are considerably inhibited.

Although S. meliloti MCM (13) is activated by the addition of some monovalent cations (especially $\mathrm{NH}_{4}{ }^{+}$ and $\left.\mathrm{K}^{+}\right)$, the addition of monovalent $\left(\mathrm{Na}^{+}, \mathrm{K}^{+}, \mathrm{NH}_{4}{ }^{+}\right.$ $\mathrm{Rb}^{+}, \mathrm{Cs}^{+}$, and $\left.\mathrm{Li}^{+}\right)$and divalent cations $\left(\mathrm{Co}^{2+}, \mathrm{Mn}^{2+}\right.$, $\mathrm{Fe}^{2+}$, and $\mathrm{Mg}^{2+}$ ) at $3 \mathrm{~mm}$ did not affect the enzyme activity of $S$. limacinum SR21 as shown in MCM from the other organisms described previously $(7,11,15$, 16).
These results presented here indicate that $S$. limacinum SR21 cells grown in the Cbl-supplemented medium contain substantial amounts of $\mathrm{Cbl}$, half of which is the $\mathrm{Cbl}$ coenzymes, especially AdoCbl that functions as the coenzyme of MCM.

Relatively high amounts of $\mathrm{MeCbl}(29.6 \%)$ were also found in the Schizochytrium cells. MeCbl mainly functions as the cofactor of Cbl-dependent methionine synthase (EC 2.1.1.13), which is widely distributed in various organisms (17). In our preliminary experiment, the enzyme activity $(0.5 \mathrm{nmol} / \mathrm{min} / \mathrm{mg}$ protein $)$ could be detected in a cell homogenate of $S$. limacinum SR21 under the anaerobic enzyme assay conditions (18).

Shirasaka et al. (5) have reported that the addition of $\mathrm{CN}-\mathrm{Cbl}$ significantly decreased the level of odd-numbered fatty acids in Schizochytrium cells. This observation suggests that the concentration of $\mathrm{Cbl}$ in the usual basal medium (artificial seawater as the Cbl source) would be insufficient to support the normal function of MCM in the methylmalonyl-CoA pathway for various cellular metabolisms. Since the concentration of $\mathrm{Cbl}$ in natural seawater appears to be very low, the Schizochytrium cells acquire Cbl through a symbiotic relationship with Cbl-synthesizing bacteria in the natural environment, as suggested recently by Croft et al. (19).

\section{REFERENCES}

1) Honda D, Yokochi T, Nakahara T, Rashukumar S, Nakagiri A, Schaumann K, Higashihara T. 1999. Molecular phylogeny of labyrinthulids and thraustochytrids based on the sequencing of $18 \mathrm{~S}$ ribosomal RNA gene. $J$ Eukaryot Microbiol 46: 637-647.

2) Yokochi T, Honda D, Higashihara T, Nakahara T. 1998. Optimization of docosahexaenoic acid production by Schizochytrium limacinum SR21. Appl Microbiol Biotechnol 49: $72-76$.

3) Morita E, Kumon Y, Nakahara T, Kagiwada S, Noguchi T. 2006. Docosahexaenoic acid production and lipidbody formation in Schizochtrium limacinum SR21. Mar Biotechnol 8: 319-327.

4) Franklin ST, Martin KR, Baer RJ, Schingoethe DJ, Hippen AR. 1999. Dietary marine algae (Schizochytrium sp.) increases concentrations of conjugated linoleic, docosahexaenoic and transvaccenic acids in milk of dairy cows. J Nutr 129: 2048-2054. 
5) Shirasaka N, Hirai Y, Nakabayashi H, Yoshizumi H. 2005. Effect of cyanocobalamin and $p$-toluic acid on the fatty acid composition of Schizochytrium limacinum (Thraustochytriaceae, Labyrinthulomycota). Mycoscience 46: 358-363.

6) Hayashi M, Yukino T, Watanabe F, Miyamoto E, Nakano Y. 2007. Effect of vitamin B12-enriched thraustochytrids on the population growth of rotifers. Biosci Biotechnol Biochem 71: 222-225.

7) Miyamoto E, Watanabe F, Yamaguchi Y, Takenaka H, Nakano Y. 2004. Purification and characterization of methylmalonyl-CoA mutase from a photosynthetic coccolithophorid alga, Pleurochrysis carterae. Comp Biochem Physiol Part B 138: 163-167.

8) Kittaka-Katsura H, Watanabe F, Nakano Y. 2004. Occurrence of vitamin $\mathrm{B}_{12}$ in green, blue, red, and black tea leaves. J Nutr Sci Vitaminol 50: 438-440.

9) Watanabe F, Takenaka S, Katsura H, Miyamoto E, Abe K, Tamura Y, Nakatsuka T, Nakano Y. 2000. Characterization of a vitamin $\mathrm{B}_{12}$ compound in the edible purple laver, Porphyra yezoensis. Biosci Biotechnol Biochem 64: 2712-2715.

10) Pezacka E, Green R, Jacobsen DW. 1990. Glutathionylcobalamin as an intermediate in the formation of cobalamin coenzymes. Biochem Biophys Res Commun 169: 443-450.

11) Fenton WA, Hack AM, Willard HF, Gertler A, Rosenberg LE. 1982. Purification and properties of methylmalonyl coenzyme A mutase from human liver. Arch Biochem Biophys 214: 815-826.

12) Han YS, Bratt JM, Hogenkamp HPC, 1984. Purification and characterization of methylmalonyl-CoA mutase from Ascaris lumbricodes. Comp Biochem Physiol 78B: 41-45.

13) Miyamoto E, Watanabe F, Charles T, Yamaji R, Inui H, Nakano Y. 2003. Purification and characterization of homodimeric methylmalonyl-CoA mutase from Sinorhizobium meliloti. Arch Microbiol 180: 151-154.

14) Francalanci F, Davis NK, Fuller JQ, Murfitt D, Leadlay PF. 1986. The subunit structure of methylmalonyl-CoA mutase from Propionibacterium shermanii. Biochem J 236: $489-494$.

15) Miyamoto E, Watanabe F, Yamaji R, Inui H, Sato K, Nakano Y. 2002. Purification and characterization of methylmalonyl-CoA mutase from a ethanol-utilizing bacterium, Methylobacterium extorquencs NR-1. J Nutr Sci Vitaminol 48: 242-246.

16) Kellermeryer RW, Allen SHG, Stjerholm R, Wood HG. 1964. Methylmalonyl isomerase IV. Purification and properties of the enzyme from propionibacteria. J Biol Chem 238: 2562-2569.

17) Matthews RG. 1999. Cobalamin-dependent methionine synthase. In: Chemistry and Biochemistry of $\mathrm{B}_{12}$ (Banerjee R, ed), p 681-706. John Wiley \& Sons, Inc., New York.

18) Banerjee R, Chen Z, Gulati S. 1997. Methionine synthase from pig liver. In: Methods in Enzymology (McCormick DB, Suttie JW, Wagner C, eds), Vol 281, p 189196. Academic Press, New York.

19) Croft MT, Lawrence AD, Raux-Deery E, Warren MJ, Smith AG. 2005. Algae acquire vitamin $\mathrm{B}_{12}$ through a symbiotic relationship with bacteria. Nature 438: 9093. 